\title{
Economic growth, energy consumption, and carbon dioxide emissions in the E7 countries: a bootstrap ARDL bound test
}

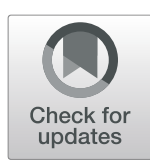

Teng Tong ${ }^{1}$, Jaime Ortiz ${ }^{2 *}$, Chuanhua $\mathrm{Xu}^{1}$ and Fangjhy $\mathrm{Li}^{1}$

\begin{abstract}
Background: International awareness of the impact of global warming and climate change is increasing. Developing countries face the task of achieving sustainable economic growth while also improving the efficiency of their energy consumption. The E7 countries (Brazil, India, Indonesia, Mexico, People's Republic of China, Russia, and Turkey) are all highly concerned with the promotion of carbon-emission-reduction strategies.

Methods: This research uses a bootstrap autoregressive distributed lag (ARDL) bound test with structural breaks to examine the cointegration and causality relations between economic growth, energy consumption, and carbon dioxide $\left(\mathrm{CO}_{2}\right)$ emissions in the $\mathrm{E} 7$ countries.

Results: There is no cointegration between economic growth, energy consumption, and $\mathrm{CO}_{2}$ emissions for People's Republic of China, Indonesia, Mexico, and Turkey. Evidence of cointegration is found for Brazil when $\mathrm{CO}_{2}$ emissions are the dependent variable and for India and Russia when energy consumption is the dependent variable. For all of the E7 countries except Indonesia, short-run Granger causality was found to exist from energy consumption to $\mathrm{CO}_{2}$ emissions and from economic growth to $\mathrm{CO}_{2}$ emissions for Brazil, India, Mexico, and People's Republic of China. Short-run Granger causality was also found from economic growth to energy consumption for Brazil, India, Indonesia, Mexico, and People's Republic of China, and from $\mathrm{CO}_{2}$ emissions to energy consumption for all E7 countries.

Conclusions: The results consistently show that energy consumption is the main cause of $\mathrm{CO}_{2}$ emissions, which has led to the emergence of global warming problems. Increases in $\mathrm{CO}_{2}$ emissions compel the $\mathrm{E} 7$ countries to develop sound policies on energy consumption and environmental pollution.
\end{abstract}

Keywords: Economic growth, Energy consumption, Carbon dioxide emissions, E7 countries, Bootstrap ARDL bound test JEL classification: C32, Q43, Q53, O44

\section{Background}

Energy is at the heart of an economy, because it ultimately enables investments and technologies that create jobs and drive growth among countries. The energy crises of 1974 and 1981 made the relationship between economic growth and energy consumption a focus of

\footnotetext{
* Correspondence: jortiz22@uh.edu

${ }^{2}$ College of Technology, University of Houston, Isabel C. Cameron Bldg. Suite. 227 D, 4235 Cullen Blvd., Houston, TX 77204, USA

Full list of author information is available at the end of the article
}

economic research, and this relationship has shown genuine concern for policy analysts [1-3]. Studies of the causal relationship between the two have reported conflicting results. For example, Lee [4] used panel data from 18 developing countries between 1975 and 2001 to investigate the causal relationship between energy consumption and gross domestic product (GDP). Granger causality results showed that energy consumption caused economic growth, but not vice versa. Conversely, Jobert and Karanfil [5] tested the relationship between energy

(c) The Author(s). 2020 Open Access This article is licensed under a Creative Commons Attribution 4.0 International License, which permits use, sharing, adaptation, distribution and reproduction in any medium or format, as long as you give appropriate credit to the original author(s) and the source, provide a link to the Creative Commons licence, and indicate if changes were made. The images or other third party material in this article are included in the article's Creative Commons licence, unless indicated otherwise in a credit line to the material. If material is not included in the article's Creative Commons licence and your intended use is not permitted by statutory regulation or exceeds the permitted use, you will need to obtain permission directly from the copyright holder. To view a copy of this licence, visit http://creativecommons.org/licenses/by/4.0/. The Creative Commons Public Domain Dedication waiver (http://creativecommons.org/publicdomain/zero/1.0/) applies to the data made available in this article, unless otherwise stated in a credit line to the data. 
consumption and economic growth in Turkey from 1960 to 2003 and found no relationship by Granger or cointegration measures. In contrast, other studies have suggested a two-way causal relationship between economic growth and energy consumption [6,7]. There is obviously a lack of consensus regarding whether the relationship between economic growth and energy consumption is a one-way causality, a two-way causality, or is completely unrelated, linearly or nonlinearly. Understanding the relationship between economic growth and energy consumption is important, however, for helping governments make sound policy decisions.

In recent years, international concern about global warming and climate change has escalated [8-10]. A major contributing factor to this problem is the increasing level of greenhouse gas carbon dioxide $\left(\mathrm{CO}_{2}\right)$ worldwide, resulting from the combustion of fossil fuels such as coal, natural gas, and oil for energy and transportation [11]. According to the 2018 report by British Petroleum (BP), $\mathrm{CO}_{2}$ emissions from energy consumption showed little or no growth in 2014-2016 but increased by 1.6\% in 2017. It is therefore necessary for all countries to play their part in balancing the need to supply the energy the world needs for growth and prosperity, with the reduction of $\mathrm{CO}_{2}$ emissions. Grippa, Schmittmann, and Suntheim identified that sustainable economic growth reflects the increasing recognition of governments that climate change impacts on financial stability, resulting in urgent calls for research into the economic costs of $\mathrm{CO}_{2}$ emissions [12].

The 2030 Agenda for Sustainable Development Goals (SDGs), adopted by the United Nations member states in 2015, provides a blueprint for inclusive and sustained economic growth along with shared prosperity and decent work for people in all countries, taking into account their own set of competencies and resource endowments [13]. There exists a sense of urgency about the goals of economic growth and sustainable development, and there is great consistency and synergy in policy measures. Because fossil fuels are not a sustainable energy source, economic growth must be aligned with changes in energy supply and consumption patterns. Within this transition, most countries face the dual task of improving energy efficiency while reducing $\mathrm{CO}_{2}$ emissions, but the options available to developed versus developing countries are substantially different [14, 15]. The focus of developed countries is to improve energy efficiency, whereas developing countries face the greater challenge of transitioning their energy structure from the consumption of coal to the increased use of natural gas and electricity while continuing to rely on fossil fuels.

The 2018 Global Energy and $\mathrm{CO}_{2}$ Status Report prepared by the International Energy Agency (IEA) [16], states that global demand for energy increased by $2.1 \%$ in 2017 , compared with $1.2 \%$ the previous year, and $0.9 \%$ on average over the previous 5 years. People's Republic of China and India accounted for more than $40 \%$ of this growth. On the other hand, Price, Waterhouse, and Coopers (PWC) [17] have suggested that emerging countries will progressively increase their share in the overall GDP. The world economy is projected to grow at an annual average rate of $2.6 \%$ between 2016 and 2050, and this growth is expected to be primarily driven by sevenemerging (E7) developing countries: Brazil, India, Indonesia, Mexico, the People's Republic of China, Russia, and Turkey. The projected annual growth rate of these countries is $3.5 \%$ over the next 40 years, compared with an annual average growth rate of $1.6 \%$ for the developed G7 countries: Canada, France, Germany, Italy, Japan, the UK, and the USA.

Hawksworth and Cookson [18] coined the term E7 to describe a group of developing countries with the fastest growing populations, which are worldly integrated, with the goal of becoming economically as strong as the G7 countries. By 2014, the E7 countries had already passed the G7 nations in terms of purchasing power parity [19]. Subsequently, PWC predicted that the E7 countries would be $75 \%$ larger than the G7 nations in purchasing power parity terms by 2050 . Whether measured by $\mathrm{CO}_{2}$ emissions or energy consumption, the E7 countries are playing a larger role in the world energy market (see Fig. 1). In 2018 , they represented $47 \%$ of the world's population, accounted for $26 \%$ of the global GDP, and captured more than $40 \%$ of the global energy consumption. An example is the People's Republic of China, which in 2005 embodied $27 \%$ of the global demand for energy, a percentage that is expected to rise to nearly $40 \%$ by 2050 . In addition, whether measured by total or per-capita share of $\mathrm{CO}_{2}$ emissions, each E7 country ranked among the world's top 20th highest $\mathrm{CO}_{2}$ polluters in 2016.

Developing economies, such as the E7, remain particularly prone to risks resulting from climate change due to their rapidly increasing levels of energy consumption and the effects of the resulting $\mathrm{CO}_{2}$ pollution [12]. Knowledge of the causal relationship and the direction between economic growth, energy consumption, and $\mathrm{CO}_{2}$ emissions (3E) is of paramount importance to policymakers. Since E7 countries have evolved into influential worldwide economic powerhouses, it is necessary to underscore their true $3 \mathrm{E}$ relationship. The phenomenal economic growth experienced by the E7 countries in the last 20 years has helped reduce the gap between them and the G7 countries. In fact, PWC pointed out that the weight of the global economy has systematically shifted towards the E7 countries. Coincidentally, the People's Republic of China and India stand at the forefront of technological progress and should exert catalytic leading roles resulting from the growth of their energy sectors [14]. 


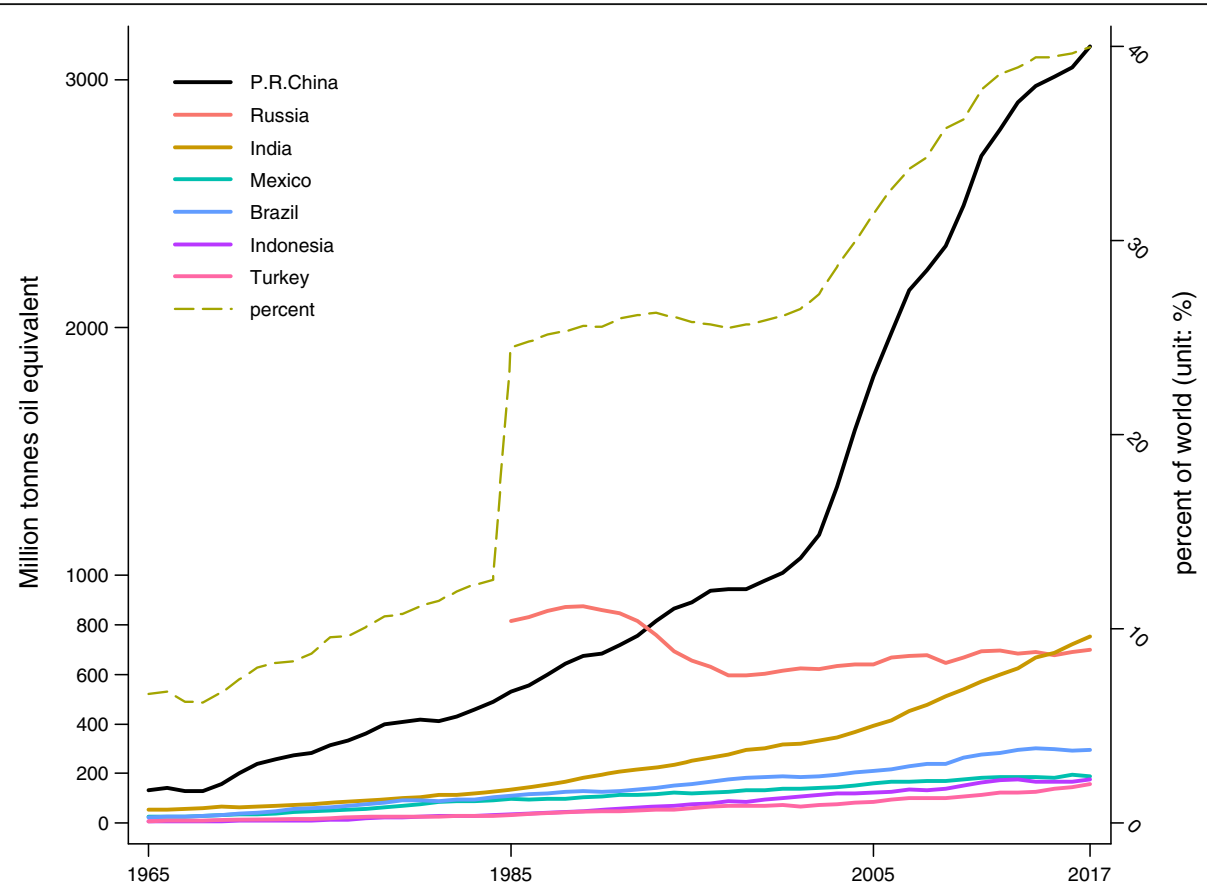

Fig. 1 Energy consumption in E7 countries (1965-2017). Source: BP Statistical Review [20]

This study fills the gap in current literature in several ways. First, it represents the E7 countries covering their 1990-2014 period. The main reason for choosing this specific sample period is that data before the 90 s are not fully reliable across E7 countries. Secondly, it looks for the longitudinal cointegration and causality relationships among $3 \mathrm{E}$ by using the bootstrap autoregressive distributed lag (ARDL) bound test. It therefore adds new empirical evidence to the ongoing debate on the $3 \mathrm{E}$ relationship. There are indeed studies on the $3 \mathrm{E}$ relationship for some isolated countries within the G20 [21], as well as their nexus for India or Turkey [22, 23]. There is, however, limited research on the $3 \mathrm{E}$ relationships of the E7 countries as a subset. The existing research has mainly used traditional time series, panel data analysis, or even the standard ARDL model [24, 25]. As mentioned in Pesaran et al. [26], these methods do not consider the two degenerated cases. Hence, our research uses the bootstrap ARDL bound test to avoid the drawbacks that may provide misleading information for policymakers. At the same time, long-run cointegration and short-run Granger causality relationships of $3 \mathrm{E}$ can be extracted from bootstrap techniques. Our findings confirm the presence of cointegration between economic growth, energy consumption, and $\mathrm{CO}_{2}$ emissions at the time we also validate the cointegration and causal relationships for all E7 countries.

This research makes novel contributions in other aspects as well. First, unlike existing cointegration or causality tests, we use the bootstrap ARDL bound method to test long-term cointegration relationships. It does not need to distinguish independent variables from dependent ones, so the method can also be used for a two-way verification, such as $x \rightarrow y$ or $y \rightarrow x$. In addition, the bootstrap ARDL bound test generates critical values to test degradation in the ARDL model. McNown et al. [27] proposed two degenerate cases without cointegration relationships, in which only one degenerate case is tested by its critical value. They initially proposed this method to not only solve endogeneity problems, but also find degradation cases, eliminating the possibility of uncertain inference.

The remainder of the paper is structured as follows. The "Literature review" section unveils the novelty of the topic and presents the literature review. The "Data and methodology" section reports the data collection, describes the statistics, introduces the traditional ARDL model, and details the bootstrap ARDL bound test. The "Results and discussion" section presents the empirical results of the unit root tests, the bootstrap ARDL cointegration test with structural breaks, and the Granger causality tests and identifies the economic implications and policy recommendations. Finally, the "Conclusions" section reports the main conclusions.

\section{Literature review}

Three general categories of literature focus on the relationships between economic growth, energy consumption, and $\mathrm{CO}_{2}$ emissions. The first addresses the relationship between $\mathrm{CO}_{2}$ emissions and economic 
growth, mainly regarding whether such relationship conforms to the environmental Kuznets curve (EKC) hypothesis. This hypothesis states that there is an inverted U-shaped relationship between certain pollutants and per-capita income [28]. Dinda [29] provides a comprehensive review of the EKC literature alongside Soytas et al. [30] and Iwata et al. [31] in relation to $\mathrm{CO}_{2}$ emissions. Studies on the EKC hypothesis have reached three different conclusions on $\mathrm{CO}_{2}$ emissions. One confirms the "inverted U shape theory" $[32,33]$. The second, however, postulates a long-term relationship between $\mathrm{CO}_{2}$ emissions and per-capita income and states that it is not an inverted $\mathrm{U}$ but an $\mathrm{N}$ or other shape [34, 35]. The third, known as the non-existence theory, claims that there is no relationship between the two [36-38]. The main problem with these early studies on EKC is that they are potentially subject to an omitted variable bias. This occurs when a statistical model leaves out one or more independent variable(s) that influences the dependent variable and correlates with one or more of the included independent variable(s) [39]. Alternatively, other scholars have studied the causality between economic growth and $\mathrm{CO}_{2}$ emissions. Salahuddin et al. [40] found a two-way Granger causal relationship between the two factors, whereas Omri et al. [41] found just a one-way Granger causality running from $\mathrm{CO}_{2}$ emissions to economic growth in some European, Central Asian, and Latin American and Caribbean countries. In recent years, different measurements and econometric methods have drawn contradictory conclusions for various countries.

The second category of literature, advanced by Kraft and Kraft [3], concerns the relationship between energy consumption and economic growth. Ozturk [42] suggests that there are four general types of relationships therein. The first, the growth hypothesis, predicts that energy consumption will cause economic growth, meaning that energy protection policies may stifle GDP [39, 43, 44]. The second, the protection hypothesis, claims energy consumption has no effect on economic growth, and that energy conservation policies do not necessarily have a negative effect on actual GDP [4-46]. The third, the feedback hypothesis, states that energy consumption and economic growth have a complementary interaction with each other [47-49]. Finally, the neutral hypothesis suggests that energy consumption does not correlate with economic growth, meaning that energy conservation policies would have limited influence on economic growth $[15,36,42]$.

The third category of research has studied 3E relationships. Soytas et al. [30] introduced energy consumption into the relationship between GDP and $\mathrm{CO}_{2}$ emissions to circumvent a potential omitted variable bias. These results show that, in the USA, income does not cause $\mathrm{CO}_{2}$ emissions, but energy consumption does. Apergis and Payne [6] found that for six Central American countries over the period 1971-2004, long-term equilibrium in energy consumption had a positive and statistically significant effect on $\mathrm{CO}_{2}$ emissions, while real GDP exhibited an inverted U-shape associated with the EKC hypothesis. Pao and Tsai [50] studied Brazil, Russia, India, and the People's Republic of China (BRIC) from 1971 to 2005. Their findings suggest that, except for Russia in 1990-2005, there was a bidirectional strong causality between energy consumption and $\mathrm{CO}_{2}$ emissions, and a bidirectional mild long-run causality between energy consumption and GDP. They also found a strong shortrun unidirectional causality between $\mathrm{CO}_{2}$ emissions and energy consumption as well as GDP.

Extant studies have indeed surveyed much of the 3E relationships through various econometric techniques across continents and regions. Table 1 summarizes the results found for several countries since 2010. It becomes clear that research on the $3 E$ relationships has been widely scrutinized via methodologies including panel cointegration tests $[8,10,15,52,53]$ and nonlinear causality tests [51]. In terms of surveying cointegration and causality between macroeconomic variables for small samples, panel data analysis seems to be the method of choice.

Another econometric approach is the ARDL bound test proposed by Pesaran et al. [26]. Using this method, Jalil and Mahmud [55] investigated the causality between $\mathrm{CO}_{2}$ emissions and economic growth using time series data pertaining to 1975-2005 for the People's Republic of China. The results show that a one-way causality runs from economic growth to $\mathrm{CO}_{2}$ emissions. Ozturk and Acaravci [23] examined the long-run and causal relationship of 3E in Turkey over the period 1968-2005. Their results show the existence of a long-run relationship between the variables, but neither $\mathrm{CO}_{2}$ emissions nor energy consumption cause GDP. Asongu et al. [24] revisited the $3 \mathrm{E}$ relationship in 24 African countries using a panel ARDL approach. They found the presence of a long-run relationship among $3 \mathrm{E}$ where causality runs from GDP and $\mathrm{CO}_{2}$ emissions to energy consumption. However, there were no short-run causalities from $\mathrm{CO}_{2}$ emissions to GDP, from GDP to energy consumption, or from energy consumption to GDP. Magazzino [56] looked at the relationship among GDP, $\mathrm{CO}_{2}$ emissions, and energy use in South Caucasus countries and Turkey over the 1992-2013 period using a time series ARDL approach and uncovered a long-run relationship between these variables. Alam et al. [57] examined the impacts of income, energy consumption, and population growth on $\mathrm{CO}_{2}$ emissions, using time series data from 1970 to 2012, for Brazil, India, Indonesia, and the People's Republic of China. Their results showed that both GDP and energy consumption have a positive effect on 
Table 1 The 3E nexus found for various countries, 2010-2018

\begin{tabular}{|c|c|c|c|c|c|}
\hline Authors & Variables & Region & Period & Methodology & Findings \\
\hline Pao and Tsai [50] & $\mathrm{CO}_{2}, \mathrm{EC}, \mathrm{GDP}$ & BRIC countries & $1971-2005$ & VECM; VAR & $\begin{array}{l}\text { - Bidirectional strong Granger causality between } \mathrm{EC} \text { and } \mathrm{CO}_{2} \\
\text { output } \\
\text { - Bidirectional mild long-run relationship between EC } \\
\text { and GDP } \\
\text { - Causality running from EC to GDP in the short-run } \\
\text { - Strong negative causality running from } \mathrm{CO}_{2} \text { output } \\
\text { to GDP }\end{array}$ \\
\hline Wang et al. [10] & $\mathrm{CO}_{2}, \mathrm{EC}, \mathrm{GDP}$ & $\begin{array}{l}28 \text { Provinces in the } \\
\text { People's Republic } \\
\text { of China }\end{array}$ & $1995-2007$ & $\begin{array}{l}\text { Panel cointegration; } \\
\text { panel VECM }\end{array}$ & $\begin{array}{l}\text { - Bidirectional causality between } \mathrm{CO}_{2} \text { and } \mathrm{EC} \text {, also } \\
\text { between } \mathrm{EC} \text { and } \mathrm{GDP} \\
\text { - } \mathrm{EC} \text { and economic growth are the long-run causes } \\
\text { for } \mathrm{CO}_{2} \text { emissions } \\
-\mathrm{CO}_{2} \text { emissions and economic growth are the } \\
\text { long-run causes for } \mathrm{EC}\end{array}$ \\
\hline Wang et al. [51] & $\mathrm{GDP}, \mathrm{EC}, \mathrm{CO}_{2}$ & $\begin{array}{l}\text { People's Republic of } \\
\text { China }\end{array}$ & 1978-2012 & $\begin{array}{l}\text { Linear and nonlinear } \\
\text { causality }\end{array}$ & $\begin{array}{l}\text { - Linear and nonlinear unidirectional causality from } \mathrm{CO}_{2} \\
\text { emissions to GDP } \\
\text { - Linear and nonlinear bidirectional causality between } \\
\mathrm{EC} \text { and } \mathrm{CO}_{2} \text { emissions } \\
\text { - Unidirectional linear causality from EC to GDP } \\
\text { - Nonlinear unidirectional causality from GDP to EC }\end{array}$ \\
\hline Magazzino [52] & $\mathrm{GDP}, \mathrm{EC}, \mathrm{CO}_{2}$ & $\begin{array}{l}\text { South Caucasus } \\
\text { and Turkey }\end{array}$ & 1992-2013 & Panel VAR & $\begin{array}{l}-\mathrm{CO}_{2} \text { has a negative effect on energy use } \\
\text { - Real GDP has no effect on energy use } \\
\text { - Energy use has no effect on real GDP }\end{array}$ \\
\hline Chen et al. [8] & $\mathrm{CO}_{2}, \mathrm{EC}, \mathrm{GDP}$ & 188 countries & $1993-2010$ & $\begin{array}{l}\text { Panel cointegration; } \\
\text { VECM }\end{array}$ & $\begin{array}{l}\text { - Long-run relationships between GDP, } \mathrm{EC} \text {, and } \mathrm{CO}_{2} \text { for all } \\
\text { countries } \\
\text { - } \mathrm{EC} \text { negatively affects GDP in the world as a whole and } \\
\text { developing countries, but not in developed countries } \\
\text { - Unidirectional causality from } \mathrm{EC} \text { to } \mathrm{CO}_{2} \text { exists both on } \\
\text { developing and developed countries }\end{array}$ \\
\hline Magazzino [53] & $\mathrm{GDP}, \mathrm{EC}, \mathrm{CO}_{2}$ & 19 APEC countries & 1960-2013 & Panel VAR & $\begin{array}{l}\text { - No long-run relationship between GDP, EC and } \mathrm{CO}_{2} \\
\text { - No causal relationship between real GDP and energy } \\
\text { use } \\
\text { - Causal relationship exist between GDP and energy } \\
\text { in } 9 \text { countries }\end{array}$ \\
\hline Mirza and Kanwal [54] & $\mathrm{GDP}, \mathrm{EC}, \mathrm{CO}_{2}$ & Pakistan & $1971-2009$ & ARDL; VECM & $\begin{array}{l}\text { - Short-run, long-run, and strong Granger causality } \\
\text { results indicate bidirectional causalities among } \mathrm{EC} \text {, } \\
\mathrm{GDP} \text {, and } \mathrm{CO}_{2} \text { emissions }\end{array}$ \\
\hline Doğan [15] & $\mathrm{CO}_{2}, \mathrm{FD}, \mathrm{EC}, \mathrm{GDP}$ & E7 countries & 1990-2014 & Panel cointegration & $\begin{array}{l}\text { - No long-term relationship between } \mathrm{CO}_{2} \text { emissions } \\
\text { and } \mathrm{FD} \\
\text { - Positive effect of } \mathrm{EC} \text { on } \mathrm{CO}_{2} \text { emissions } \\
\text { - Positive effect of economic growth on } \mathrm{CO}_{2} \text { emissions } \\
\text { in long-term }\end{array}$ \\
\hline Pao and Chen [21] & $\mathrm{CO}_{2} \mathrm{EC}, \mathrm{GDP}$ & $\mathrm{G} 20$ & $1991-2016$ & Panel cointegration & $\begin{array}{l}\text { - Long-run equilibrium relationship among } \mathrm{CO}_{2} \text { emissions, } \\
\text { consumption of fossil fuels, GDP, and clean energy } \\
\text { consumption }\end{array}$ \\
\hline
\end{tabular}

Note: ARDL autoregressive distributed lag procedure, EC energy consumption, FD financial development, VAR Vector Autoregressive Model, VECM Vector Error Correction Model

$\mathrm{CO}_{2}$ emissions in these four countries. McNown et al. [27] pointed out that the ARDL bound test has the advantage of solving endogeneity problems and eliminating the possibility of inconclusive inference.

Hereafter, an increasing number of studies began using the bootstrap technique and causality based on the ARDL model. Examples include Goh et al.'s study on the energy consumption-economic growth relationship for 22 OECD countries [58], and Lin et al.'s study on the coal consumption, $\mathrm{CO}_{2}$ emissions, and economic growth nexus for the People's Republic of China and India [59]. However, despite the abovementioned advantages, no research using the bootstrap ARDL bound test has been carried out on the E7 countries. Most studies on the $3 \mathrm{E}$ relationship identify a positive cause-and-effect relationship between $\mathrm{CO}_{2}$ and energy consumption, especially those focusing on developing countries $[8,10,24,45,52$, 55]. Unfortunately, the results lack sufficient strength for verification of a linear or nonlinear causality between
$\mathrm{CO}_{2}$ emissions and economic growth or between energy consumption and economic growth, in order to confirm the EKC hypothesis.

\section{Data and methodology}

The three variables used in this study are per-capita GDP in constant 2010 US\$, per-capita total primary energy consumption in a kilogram of oil equivalent (kgoe), and per-capita $\mathrm{CO}_{2}$ emissions in metric tons (mt). These variables are examined for the E7 countries over the period 1971 to 2014, except for Russia (1992-2014) because of data irregularities. Data for all sampled countries were obtained from the World Development Indicators ${ }^{1}$ of the World Bank. Logarithms were applied to all variables to ameliorate heteroscedasticity issues. The inter-quartile

${ }^{1}$ World Bank Indicators (WBI), see more details: https://databank. worldbank.org/source/world-development-indicators 
range (IQR) shows the absence of outliers for the variables (see Table 2).

We used the bootstrap ARDL model to examine the nexus among economic growth, energy consumption, and $\mathrm{CO}_{2}$ emissions for the E7 countries. The bootstrap ARDL bound test with structural breaks uses the principle of self-regression and multiple loop calibrations to approximate the time series data for verification of the expected results.

\section{Unit root test}

Time series analysis requires firstly performing the unit root test to check whether the collected data is stationary, in order to avoid false regressions. A steady state means that statistics such as the mean and variance do not change over time. In other words, the selfcovariance and the variance are fixed finite constant values. We applied the augmented Dickey-Fuller (ADF), Phillips and Perron (PP) [60], Elliott et al, (DF-GLS) [61], and the Kwiatkowski-Phillips-Schmidt-Shin (KPSS) [62] unit root tests for LGDP, LEC, and $\mathrm{LCO}_{2}$. In addition, we also used the Zivot and Andrew (Z-A) unit root test [63] which allows for breaks at a point in the intercept term and/or the line trend items [63], as well as the Lee and Strazicich (LS) [64] unit root test with two structural breaks to strengthen the validity of the univariate unit root tests.

\section{Bootstrap ARDL bound test}

The ARDL bound test allows a better understanding of the cointegration of the series in the model. A Monte Carlo simulation was used to estimate the size and power characteristics of endogeneity. The asymptotic threshold of the simulation has only a small effect. If the re-sampling process is applied properly, the pilot-to-test ratio is determined, and the asymptotic check in the ARDL bound test based on the size and power characteristics performs better. The asymptotic threshold describes the extension of the validation framework under an alternative degradation, as well as the threshold itself generated by the bootstrap ARDL bound test that is based on the Granger causality test. The standard Granger causality determines the direction of the short-term causal relationship. If $y$ is due to a variable, no agreement is found between $y$ and $x$. The Granger causality test of $x \rightarrow y$ should only include the hysteresis difference of $x$. If there is a cointegration relationship between the variables, then the dependent and independent variables form a fixed linear combination. The hysteresis term can be considered as $I(0)$, and the Granger causality test of $x \rightarrow y$ should include the hysteresis difference of $x$ and the hysteresis level of $x$. The
ARDL bound test [26] has a time series of mixed integration sequences that is defined as:

$$
y_{t}=a+\sum_{i=1}^{k} \alpha_{i} y_{t-i}+\sum_{i=1}^{k} \beta_{i} x_{t-i}+\sum_{j=1}^{l} \psi_{j} D_{t, j}+\mu_{t}
$$

In the case of an exogenous weak regression, these regression factors are not affected by the variables in the long-run. The model neither precludes the existence of cointegration between regressions nor assumes that the dependent variable of the regression exhibits short-term Granger causality.

The ARDL model with three variables is:

$$
\begin{aligned}
y_{t}= & a+\sum_{i=1}^{k} \alpha_{i} y_{t-i}+\sum_{i=1}^{k} \beta_{i} x_{t-i}+\sum_{i=1}^{k} \delta_{i} z_{t-i} \\
& +\sum_{j=1}^{l} \psi_{j} D_{t, j}+\mu_{t}
\end{aligned}
$$

where $i$ and $j$ are the indicators of the lag period, $i=1$, $2, \ldots, k ; j=1,2, \ldots, k . t$ represents time $t=1,2, \ldots, T$. The $y_{t}$ in the equation is the interpreted variable and $x_{t}$ is the explanatory variable; $D_{t, j}$ is a dummy variable. The error term is $\mu_{t}$, and Eq. (2) is rewritten and expanded in an error correction representation as:

$$
\begin{aligned}
\Delta \mathrm{y}_{t}= & \gamma_{0}+\sum_{i=1}^{k-1} \gamma_{1} \Delta y_{t-i}+\sum_{i=1}^{k-1} \gamma_{2} \Delta x_{t-i} \\
& +\sum_{i=1}^{k-1} \gamma_{3} \Delta z_{t-i}+\sum_{j=1}^{l} \gamma_{4} D_{t, j}+\theta_{1} y_{t-1} \\
& +\theta_{2} x_{t-1}+\theta_{3} z_{t-1}
\end{aligned}
$$

where $\quad \theta_{1}=-\left(1-\sum_{i=0}^{k} \alpha_{i}\right) ; \theta_{2}=\sum_{i=0}^{k} \beta_{i} ; \theta_{3}=\sum_{i=0}^{k} \delta_{i}$;

other parameters are the function values of the original parameters in Eq. (2).

According to Pesaran et al. [26], the cointegration test needs to be an $F$ test or a $t$ test. The following assumptions are made:

$$
H_{0}: \theta_{1}=\theta_{2}=\theta_{3}=0 \text { or } H_{0}: \theta_{1}=0
$$

McNown et al. [27] proposed adding the original ARDL model to a lag period for independent variables where the null hypothesis is $\theta_{2}=\theta_{3}=0$. Doing this creates more complete conditions for testing the cointegration relationship proposed by Pesaran et al. [6]. Then, the following three null hypotheses must be rejected:

The null hypothesis error term $F_{1}$ is tested as $H_{0}: \theta_{1}=$ $\theta_{2}=\theta_{3}=0$.

The $t$ test for the lag dependent variable is $H_{0}: \theta_{1}=0$. The $F_{2}$ test for the lag independent variable is $H_{0}: \theta_{2}=$ $\theta_{3}=0$. 


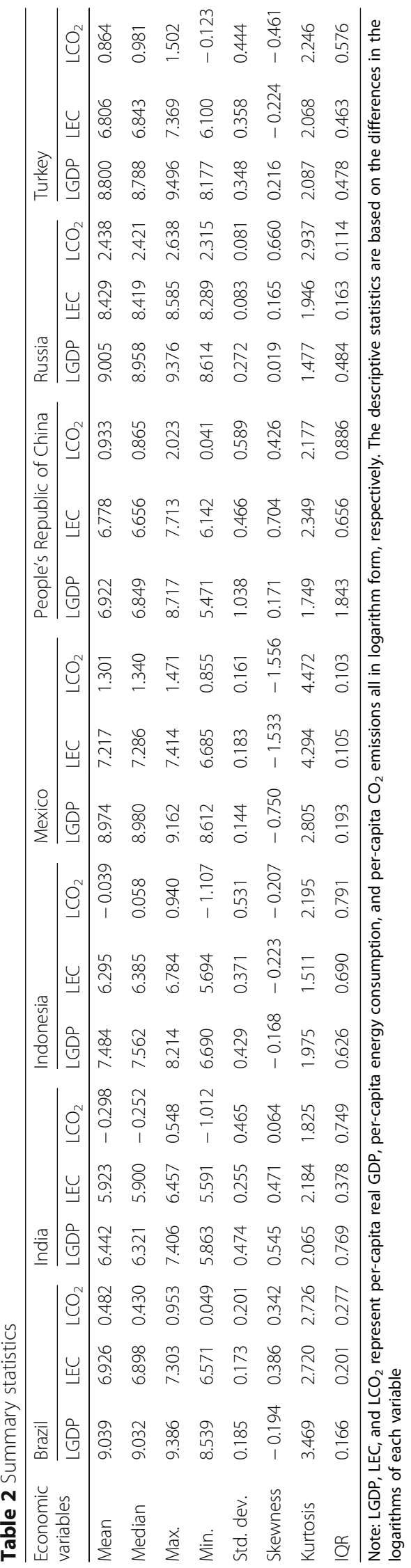


Based on three null hypotheses, McNown et al. [27] explain two degenerates of Pesaran et al. [26]. The two degeneration cases are as follows:

Degenerate case \#1. The $F 1$ test and the $t$ test for the lag dependent variable are significant, but the F2 test for the lag independent variable is not significant.

Degenerate case \#2. The $F 1$ and $F 2$ tests for the lag dependent variable are significant, but the $t$ test for the lag dependent variable is not significant.

Pesaran et al. [26] excluded degeneration case \#1, and if they did not consider the integration order of the dependent variable, it must be $I(1)$. To solve this problem, McNown et al. [27] used the bootstrap ARDL bound test as an additional test of the lagging independent coefficient. If there is a cointegration relationship between the dependent variable and an independent variable, the above three virtual hypotheses will simultaneously be rejected, and the interpreted and explanatory variables will be stable linear coincidences.

If, after testing the long-term 3E relationships, we find no cointegration relationships between $y, x$, and $z$, we use the Granger causality test for $x$ and $z$, which should include the difference in hysteresis on $x$ or $z$. We test $\gamma_{2}$ $=0$ or $\gamma_{3}=0$ in Eq. (3). However, if there is cointegration between the dependent variable and the independent variable, this means that they form a fixed linear combination. In this case, the short-term relationship test should include the hysteresis difference of $x$ or $z$ and the hysteresis level of $x$ or $z$; that is, test $\gamma_{2}$ and $\theta_{2}$ or $\gamma_{3}$ and $\theta_{3}$.

\section{Results and discussion Unit root test}

As mentioned, a prerequisite of the bootstrap ARDL bound test is the performance of unit root tests to verify the three variables are stationary. We used the ADF, DF-GLS, PP, and KPSS tests to achieve such a task. Table 3 reveals that all variable sequences were no more integrated than $I$ (1) with the ADF, DF-GLS, and PP tests. However, the KPSS test for LGDP for the People's Republic of China and the LEC and $\mathrm{LCO}_{2}$ for Russia does reject the null hypothesis of stationarity. Similarly, Tables 4 and 5 present the results of the Z-A and LS unit root tests. Table 4 reports the stationarity of variables employed in level and first differences where a break at a point in the intercept and/or the slope of the trend function is allowed. All variables are $I(1)$ process or less. Table 5 shows the variables rejecting the null hypothesis that the series has a unit root on first difference. We therefore conclude they are all stationary at either $I(0)$ or $I(1)$, which is consistent with the premise of bootstrap ARDL bound test. ${ }^{2}$

\section{Bootstrap ARDL cointegration test with structural breaks}

The bootstrap ARDL bound test provides a better insight into the cointegration status of the series when structural breaks are identified [27]. We followed Bai and Perron [65] to determine the structural breaks in the equation for each country. Multiple breakpoints were plugged into the ARDL model as dummy variables. Table 6 reports the estimation and testing of Eq. (3) using the bootstrap ARDL bound test. Each ARDL equation passed all diagnostic tests for autocorrelation, nonnormality, and heteroscedasticity. These lag lengths were determined using the AIC. The $F_{1}{ }^{\prime \prime}, F_{2}{ }^{\prime \prime}$, and $t^{\prime \prime}$ columns present values for the 0.10 significance level, generated by the ARDL bootstrap procedure. The bootstrap ARDL bound test allows for the renormalization of the ARDL equation to treat every series as a dependent variable. A degenerate case \#2 exists for Indonesia and the People's Republic of China where energy consumption serves as the dependent variable, and Mexico where GDP serves as the dependent variables, since the $F_{1}$ and $F_{2}$ tests for the lagged dependent variable were significant but their $t$ tests were not. For the People's Republic of China, Indonesia, Mexico, and Turkey, no cointegration was found for economic growth, energy consumption, or $\mathrm{CO}_{2}$ emissions. Evidence of cointegration was found for Brazil when $\mathrm{CO}_{2}$ emissions are the dependent variable and for India and Russia when energy consumption was the dependent variable.

\section{Granger causality tests}

Table 7 shows the long-term causality tests on Brazil, India, and Russia based on the cointegration analysis. The results show that economic growth has a positive Granger causality effect on energy consumption only for India, implying that its economic growth will largely be accompanied by increasing energy consumption in the long-run. Table 8 and Fig. 2 present the short-run Granger causality results between economic growth, energy consumption, and $\mathrm{CO}_{2}$ emission for the E7 countries. There is evidence of a firm short-run Granger causality from energy consumption to economic growth for Brazil, India, Indonesia, Mexico, and Turkey. Short-run Granger causality from $\mathrm{CO}_{2}$ emissions to economic growth is present for all E7 countries, suggesting that even though no cointegration exists when economic growth is the

\footnotetext{
${ }^{2}$ We performed multiple linear and nonlinear unit root tests to improve the alleged deficiency of the univariate unit root tests and to identify unknown structural breaks. These results available upon request were all consistent.
} 


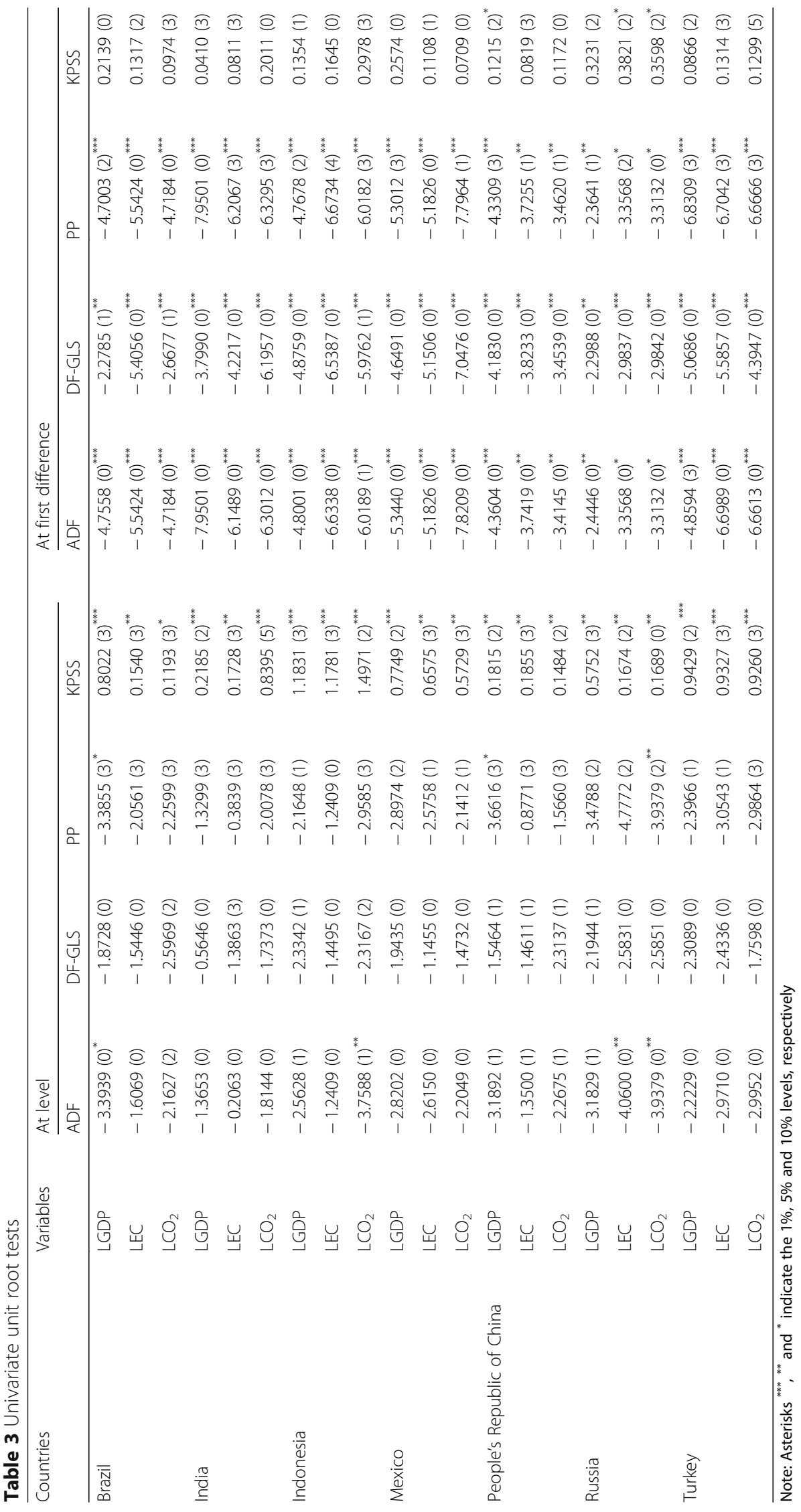




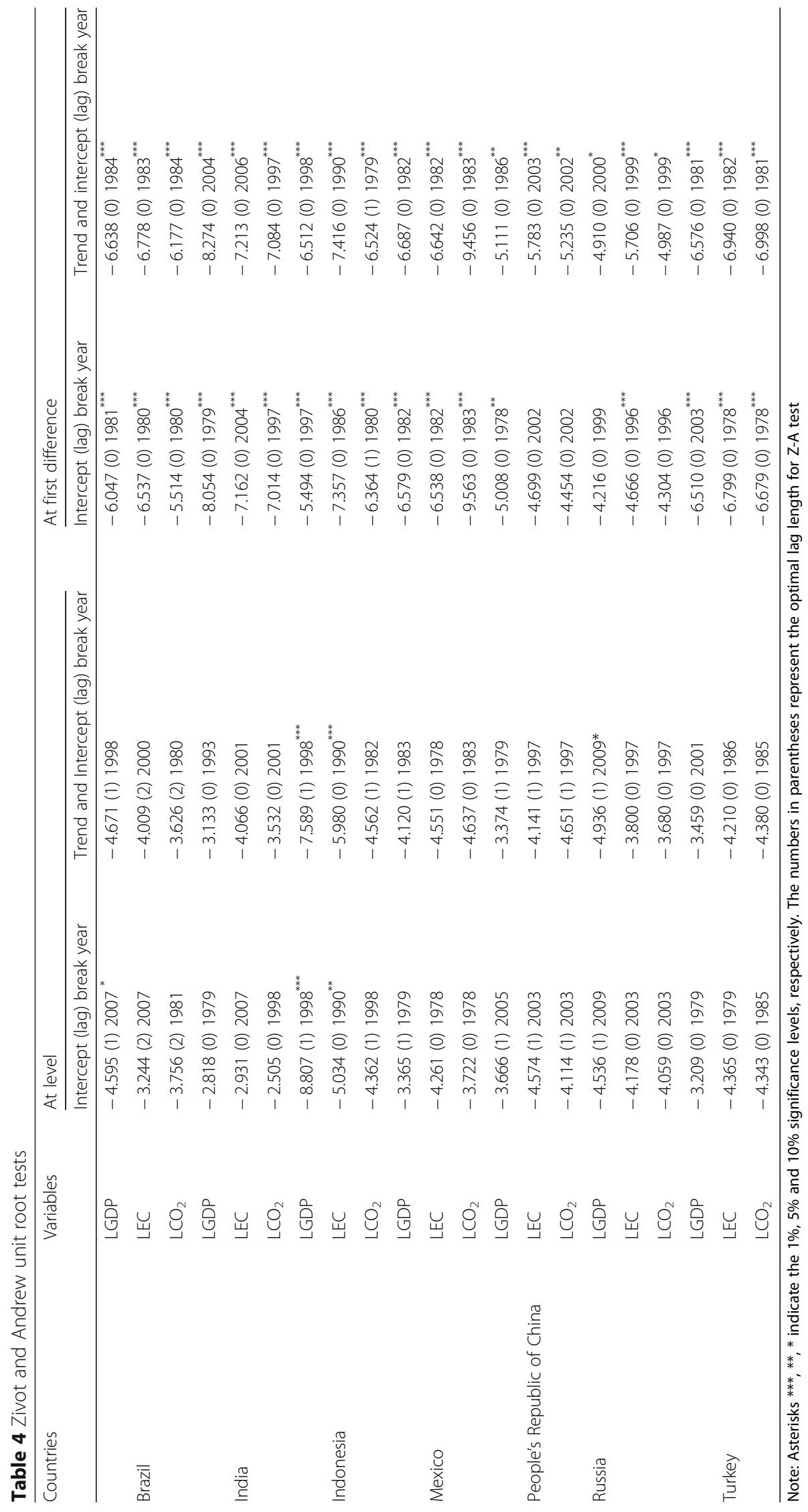


Table 5 Lee and Strazicich LM unit root tests results on first difference

\begin{tabular}{|c|c|c|c|c|c|c|c|}
\hline \multirow[t]{2}{*}{ Countries } & \multirow[t]{2}{*}{ Variables } & \multicolumn{3}{|l|}{ Intercept } & \multicolumn{3}{|c|}{ Trend and Intercept } \\
\hline & & Test statistic (lag) & TB1 & $\overline{\text { TB2 }}$ & $\overline{\text { Test statistic (lag) }}$ & TB1 & $\overline{\mathrm{TB} 2}$ \\
\hline \multirow[t]{3}{*}{ Brazil } & LGDP & $-3.418(0)^{*}$ & 1977 & 1979 & $-7.362(4)^{* * *}$ & 1978 & 1981 \\
\hline & LEC & $-5.160(4)^{* * *}$ & 1979 & 2006 & $-7.045(4)^{* * *}$ & 1979 & 1987 \\
\hline & $\mathrm{LCO}_{2}$ & $-5.491(0)^{* * *}$ & 1978 & 1982 & $-5.883(0)^{* * *}$ & 1979 & 1982 \\
\hline \multirow[t]{3}{*}{ India } & LGDP & $-4.616(1)^{* * *}$ & 1983 & 1987 & $-8.031(0)^{* * *}$ & 1977 & 1980 \\
\hline & LEC & $-4.737(3)^{* * *}$ & 1984 & 1994 & $-6.374(3)^{* *}$ & 1997 & 2007 \\
\hline & $\mathrm{LCO}_{2}$ & $-4.721(1)^{* * *}$ & 1996 & 2000 & $-6.797(0)^{* *}$ & 1976 & 1990 \\
\hline \multirow[t]{3}{*}{ Indonesia } & LGDP & $-5.646(0)^{* * *}$ & 1979 & 1995 & $-9.588(1)^{* * *}$ & 1995 & 1999 \\
\hline & LEC & $-6.212(0)^{* * *}$ & 1977 & 1982 & $-6.745(1)^{* *}$ & 1988 & 1994 \\
\hline & $\mathrm{LCO}_{2}$ & $-6.105(1)^{* * *}$ & 1986 & 1999 & $-6.862(1)^{* * *}$ & 1986 & 2008 \\
\hline \multirow[t]{3}{*}{ Mexico } & LGDP & $-6.483(0)^{* * *}$ & 1977 & 1981 & $-7.304(4)^{* * * *}$ & 1979 & 1987 \\
\hline & LEC & $-5.077(0)^{* * *}$ & 1977 & 1979 & $-6.545(4)^{* *}$ & 1980 & 2000 \\
\hline & $\mathrm{LCO}_{2}$ & $-7.969(0)^{* * *}$ & 1977 & 1980 & $-9.657(0)^{* * *}$ & 1977 & 1982 \\
\hline \multirow[t]{3}{*}{ People's Republic of China } & LGDP & $-4.431(2)^{* * *}$ & 1976 & 1988 & $-5.983(5)^{*}$ & 1986 & 2003 \\
\hline & LEC & $-4.151(0)^{* * *}$ & 1977 & 2009 & $-7.656(3)^{* * *}$ & 1988 & 2000 \\
\hline & $\mathrm{LCO}_{2}$ & $-3.851(3)^{* *}$ & 1993 & 1997 & $-6.330(3)^{*}$ & 1993 & 2000 \\
\hline \multirow[t]{3}{*}{ Russia } & LGDP & $-3.806(0)^{* *}$ & 1998 & 2007 & $-11.61(5)^{* * *}$ & 2003 & 2007 \\
\hline & LEC & $-4.033(4)^{* *}$ & 2001 & 2007 & $-6.262(2)^{* *}$ & 1997 & 2007 \\
\hline & $\mathrm{LCO}_{2}$ & $-4.901(2)^{* * *}$ & 1997 & 2009 & $-6.772(2)^{* *}$ & 1997 & 2007 \\
\hline \multirow[t]{3}{*}{ Turkey } & LGDP & $-5.423(0)^{* * *}$ & 1977 & 1979 & $-7.521(4)^{* * *}$ & 1992 & 1998 \\
\hline & LEC & $-6.549(0)^{* * *}$ & 1977 & 2005 & $-6.887(0)^{* * *}$ & 1977 & 1987 \\
\hline & $\mathrm{LCO}_{2}$ & $-6.576(0)^{* * *}$ & 1978 & 2003 & $-6.516(0)^{* *}$ & 1977 & 1985 \\
\hline
\end{tabular}

Note: Asterisks ${ }^{* * *},{ }^{* *}$ and $*$ indicate the $1 \%, 5 \%$ and $10 \%$ significance levels, respectively. Numbers in parentheses represent the optimal number of lag terms, break date, test statistics, and critical $t$ values. TB1 and TB2 represent time break 1 and time break 2

dependent variable, $\mathrm{CO}_{2}$ emissions and energy consumption are still important short-run determinants of economic growth for them.

Similarly, short-run Granger causality exists from energy consumption to $\mathrm{CO}_{2}$ emissions across all E7 countries except Indonesia, and from economic growth to $\mathrm{CO}_{2}$ emissions for Brazil, India, Mexico, and the People's Republic of China. Regarding energy consumption, Granger causality is observed from economic growth to energy consumption for Brazil, India, Indonesia, Mexico, and the People's Republic of China in the short-run, and from $\mathrm{CO}_{2}$ emissions to energy consumption for all E7 countries.

\section{Economic implications}

There is cointegration between energy consumption, economic growth, and $\mathrm{CO}_{2}$ emissions for Brazil, India, and Russia, but not for Indonesia, Mexico, the People's Republic of China, and Turkey. Evidence of cointegration is found for Brazil when $\mathrm{CO}_{2}$ emissions are the dependent variable, which suggests that economic growth and energy consumption are the main factors of increased $\mathrm{CO}_{2}$ emissions. As for India and Russia, cointegration exists when energy consumption is the dependent variable, which suggests that economic growth is the main determinant of increased energy consumption in the long-run. However, no cointegration is found when economic growth serves as the dependent variable, which means neither energy consumption nor $\mathrm{CO}_{2}$ emissions can account for the economic growth for the E7 countries in the long-run. The Granger causality based on the bootstrap ARDL bound test confirms a bidirectional causality relationship between energy consumption and $\mathrm{CO}_{2}$ emissions for all E7 countries except Indonesia, which is consistent with the fact that energy consumption does produce $\mathrm{CO}_{2}$ emissions.

The economic implications of the above results are that energy consumption, as the main cause of $\mathrm{CO}_{2}$ emissions, has led to the emergence of global warming and the need for developing countries to use energy more efficiently. These countries should follow energy conservation and energy efficient policies to control $\mathrm{CO}_{2}$ emissions. As representatives of developing countries, an increase in $\mathrm{CO}_{2}$ emissions compels E7 countries to develop stringent policies on energy consumption. In addition, they should consider implementing $\mathrm{CO}_{2}$ taxation strategies, transforming to renewable energy, and promoting the use of new sources of energy. These 


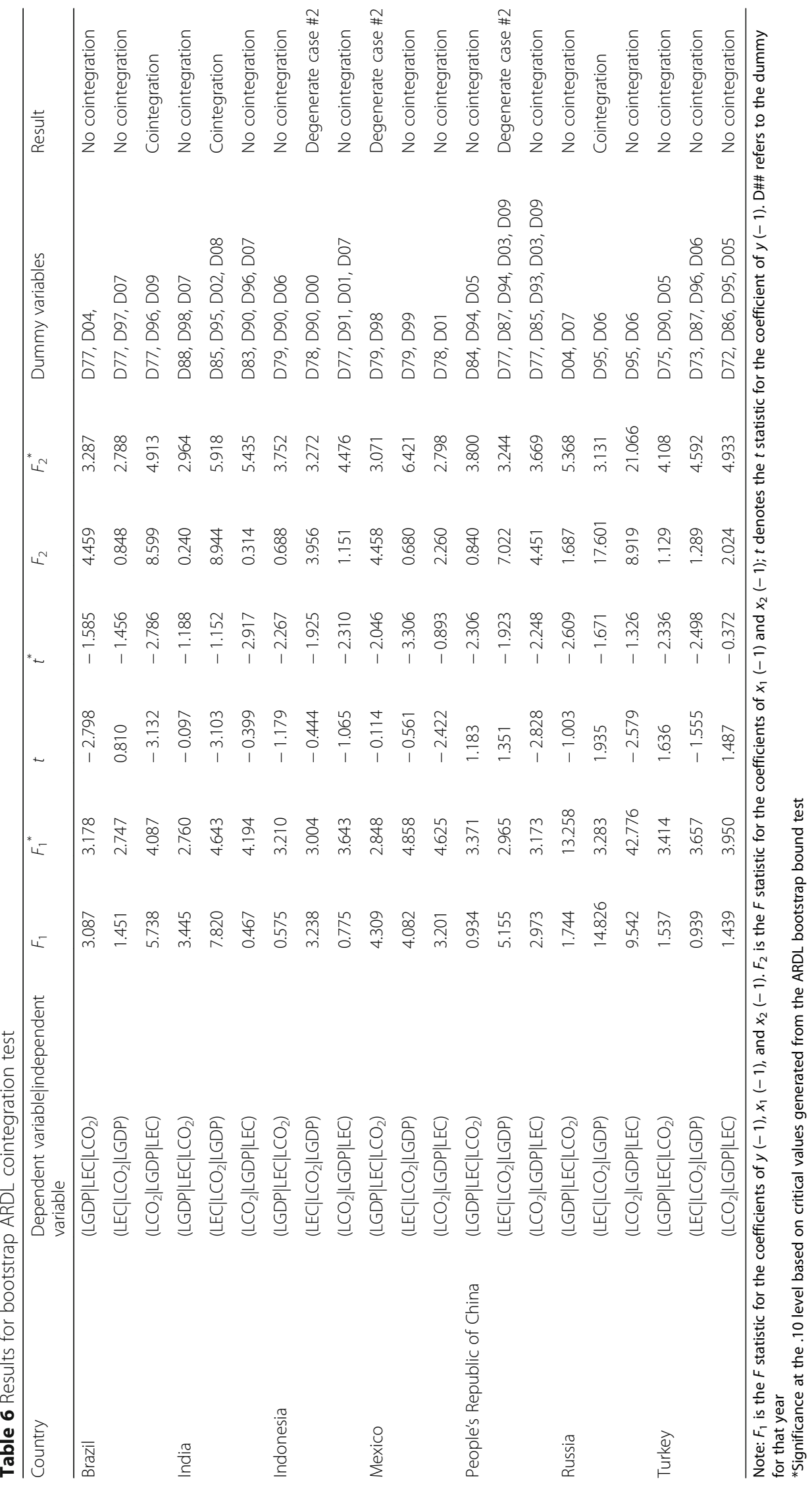


Table 7 Long-run causality test

\begin{tabular}{|c|c|c|c|c|}
\hline \multirow[t]{2}{*}{ Country } & & \multirow{2}{*}{$\frac{\mathrm{LGDP}}{F \text { statistics ( } p \text { value) (sign) }}$} & \multirow{2}{*}{$\frac{\text { LEC }}{F \text { statistics ( } p \text { value) (sign) }}$} & \multirow{2}{*}{$\frac{\mathrm{LCO}_{2}}{F \text { statistics ( } p \text { value) (sign }}$} \\
\hline & & & & \\
\hline Brazil & $\mathrm{LCO}_{2}$ & $2.136213 /[0.1536](-)$ & $2.460071 /[0.1266](+)$ & -- \\
\hline India & LEC & $5.297746^{* *} /[0.0328](+)$ & -- & $1.561488 /[0.2266](+)$ \\
\hline Russia & LEC & $0.352065 /[0.5640](-)$ & -- & $0.699432 /[0.4193](+)$ \\
\hline
\end{tabular}

Note: Asterisk ** indicates the $5 \%$ significance level

Square brackets indicate the characterization factor of the $p$ value. No cointegration and its causality test involve only lag variables

countries can also address global warming and climatic instability by setting realistic mitigation commitments of $\mathrm{CO}_{2}$ emissions.

The Granger causality test supports, for Brazil and Mexico, the presence of a positive bidirectional causal relationship between energy consumption and $\mathrm{CO}_{2}$ emissions, and a negative bidirectional causal relationship between $\mathrm{CO}_{2}$ emissions and economic growth. These results support the conventional belief that energy consumption and economic growth closely interact with each other and confirm the fact that Brazil and Mexico are energy-dependent economies. These countries require supply-side energy infrastructure policies and energy conservation policies to prevent further environmental degradation. The results also reveal a bidirectional causal relationship between energy consumption and $\mathrm{CO}_{2}$ emissions.

India portraits bidirectional causal relationships between energy consumption and economic growth, economic growth and $\mathrm{CO}_{2}$ emissions, and $\mathrm{CO}_{2}$ emissions and energy consumption. However, our results do not support the presence of reverse relationships. As in the case of Brazil and Mexico, India is an energy-dependent economy that faces the complex task of conserving energy to reduce $\mathrm{CO}_{2}$ emissions while stimulating economic growth.

Indonesia depicts a negative bidirectional causality between energy consumption and economic growth. Its current shortage of energy consumption for construction, manufacturing, and transportation is restraining future economic growth. The unidirectional relationship running from $\mathrm{CO}_{2}$ emissions to energy consumption and economic growth compels the enactment of conservation policies to reduce end energy consumption.

The People's Republic of China shows bidirectional causalities between energy consumption and $\mathrm{CO}_{2}$ emissions, and $\mathrm{CO}_{2}$ emissions and economic growth along with a unidirectional causality from economic growth to energy consumption. There are bidirectional causalities between economic growth and $\mathrm{CO}_{2}$ emissions. Empirical evidence reveals that environmental degradation has a causal impact on economic growth, while a persistent decline in environmental quality explains the severe negative externalities that surround declines in productivity. It is imperative for the People's Republic of China to take urgent action to decrease $\mathrm{CO}_{2}$ emissions by reducing its demand for energy. Similarly, Russia exemplifies a positive bidirectional Granger causality between $\mathrm{CO}_{2}$ emissions and energy consumption as well as a negative unidirectional Granger causality from $\mathrm{CO}_{2}$ emissions to economic growth. Turkey presents a positive bidirectional Granger causality of $\mathrm{CO}_{2}$ emissions and energy consumption like the People's Republic of China and Russia, while there is a unidirectional Granger causality from energy consumption and $\mathrm{CO}_{2}$ emissions to economic growth. These energy-dependent economies need supply-side energy infrastructure policies and energy conservation policies compatible with a sustainable economic growth.

This research found an inextricable unidirectional or bidirectional short-run causality between economic growth and $\mathrm{CO}_{2}$ emissions for all E7 countries. Brazil, India, and Russia showed long-run relationships between energy consumption and economic growth in respect of $\mathrm{CO}_{2}$ emissions, when the latter is the dependent variable. In Brazil, India, and Mexico, $\mathrm{CO}_{2}$ emissions would decrease over the time when GDP increases. Thus, it can be argued that these three countries may decide not to take any significant actions to impact economic growth in order to reduce their $\mathrm{CO}_{2}$ emissions. However, in the case of Indonesia and the People's Republic of China, where $\mathrm{CO}_{2}$ emissions and economic growth were found to have a positive relationship, an increase in GDP will not reduce $\mathrm{CO}_{2}$ emissions.

As for the Granger causality between energy consumption and economic growth, energy consumption Granger-cause economic growth in Brazil, India, Indonesia, Mexico and Turkey is consistent with the fact that these developing countries are at their industrialized stage. It also supports the "energy led-growth hypothesis" which predicts that, more often than not, energy protection policies are bound to stir economic growth. There was also an indication of economic growth Granger-cause energy consumption in Brazil, India, Indonesia, Mexico, and the People's Republic of China. This suggests that if economic growth increases energy consumption, the externality created out of energy use will ultimately reverse into economic growth. Under this circumstance, conservation policies are urgently required. 
Table 8 Results for Granger causality test based on ARDL model

\begin{tabular}{|c|c|c|c|c|}
\hline \multirow[t]{2}{*}{ Country } & & \multirow{2}{*}{$\begin{array}{l}\text { LGDP equation } \\
\text { F statistics ( } p \text { value) }\end{array}$} & \multirow{2}{*}{$\begin{array}{l}\text { LEC equation } \\
F \text { statistics ( } p \text { value) }\end{array}$} & \multirow{2}{*}{$\begin{array}{l}\mathrm{LCO}_{2} \text { equation } \\
F \text { statistics ( } p \text { value) }\end{array}$} \\
\hline & & & & \\
\hline \multirow[t]{3}{*}{ Brazil } & LGDP & -- & $2.405635^{*} /[0.0800](+)$ & $3.767159^{* *} /[0.0177](-)$ \\
\hline & LEC & $8.200355^{* * *} /[0.0005](+)$ & -- & $8.665529^{* * *} /[0.0004](-)$ \\
\hline & $\mathrm{LCO}_{2}$ & $8.047049^{* * *} /[0.0017](-)$ & $9.973761^{* * *} /[0.0005](+)$ & -- \\
\hline \multirow[t]{3}{*}{ India } & LGDP & -- & $10.01860^{* * *} /[0.0002](+)$ & $2.494419^{*} /[0.0842](-)$ \\
\hline & LEC & $38.67256^{* * *} /[0.0000](+)$ & -- & $59.24849^{* * *} /[0.0000](+)$ \\
\hline & $\mathrm{LCO}_{2}$ & $3.277671^{* *} /[0.0338](+)$ & $4.296970^{* *} /[0.0126](-)$ & -- \\
\hline \multirow[t]{3}{*}{ Indonesia } & LGDP & -- & $2.728564^{*} /[0.0827](-)$ & $0.485877 /[0.6202]$ (no) \\
\hline & LEC & $2.471449^{*} /[0.0768](-)$ & -- & $1.661532 /[0.2009]$ (no) \\
\hline & $\mathrm{LCO}_{2}$ & $3.369837^{* *} /[0.0303](+)$ & $2.825815^{*} /[0.0769](+)$ & -- \\
\hline \multirow[t]{3}{*}{ Mexico } & LGDP & -- & $2.641577^{*} /[0.0607](+)$ & $6.732778^{* * *} /[0.0012](-)$ \\
\hline & LEC & $29.22243^{* * *} /[0.0000](+)$ & -- & $4.472803^{* * * *} /[0.0090](+)$ \\
\hline & $\mathrm{LCO}_{2}$ & $4.520791^{* * *} /[0.0084](-)$ & $5.014765^{* * *} /[0.0053](-)$ & -- \\
\hline \multirow[t]{3}{*}{ People's Republic of China } & LGDP & -- & $5.734735^{* *} /[0.0227](-)$ & $10.60359^{* * *} /[0.0027](+)$ \\
\hline & LEC & $0.109901 /[0.9534]$ (no) & -- & $7.015114^{* * *} /[0.0016](+)$ \\
\hline & $\mathrm{LCO}_{2}$ & $6.805757^{* * *} /[0.0019](-)$ & $4.463740^{* *} /[0.0130](+)$ & -- \\
\hline \multirow[t]{3}{*}{ Russia } & LGDP & -- & $0.575145 /[0.5843]$ (no) & $0.828062 /[0.4711]$ (no) \\
\hline & LEC & $0.091798 /[0.7671]$ (no) & -- & $30.43173^{* * * *} /[0.0000](+)$ \\
\hline & $\mathrm{LCO}_{2}$ & $6.120302^{* *} /[0.0293](-)$ & $26.29907^{* * *} /[0.0000](+)$ & -- \\
\hline \multirow[t]{3}{*}{ Turkey } & LGDP & -- & $1.556601 /[0.2136]$ (no) & $1.348327 /[0.2815]$ (no) \\
\hline & LEC & $12.47108^{* * *} /[0.0001](+)$ & -- & $12.64742^{* * *} /[0.0001](+)$ \\
\hline & $\mathrm{LCO}_{2}$ & $30.21155^{* * *} /[0.0000](+)$ & $9.017897^{* * *} /[0.0001](+)$ & -- \\
\hline
\end{tabular}

Note: Asterisks $* * *,{ }^{* *}$ and $*$ indicate the $1 \%, 5 \%$ and $10 \%$ significance levels, respectively

Square brackets indicate the characterization factor of the $p$ value. No cointegration and its causality test involve only lag variables

The bootstrap ARDL bound test enabled an understanding of the long-term relationship among the $3 \mathrm{E}$ variables and used this relationship to predict changes in $\mathrm{CO}_{2}$ emissions and energy consumption in the E7 countries over time. Similarly, the $3 \mathrm{E}$ relationship must be considered in light of the particular conditions of each country, because each country presents a unique composite of social, legal, economic, political, and technological characteristics. The empirical results provide policymakers with a better understanding of the linkages

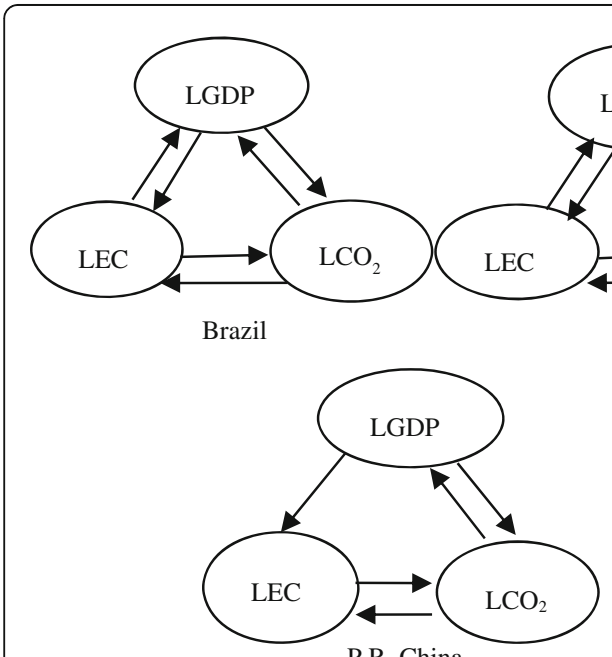

P.R. China

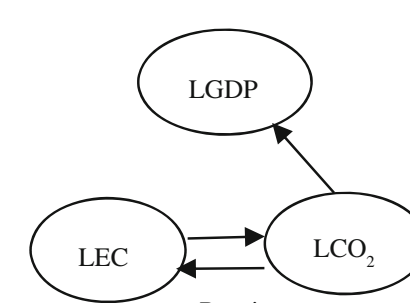

Russia

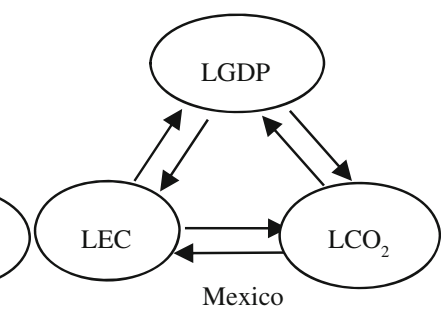

Mexico

Fig. 2 3E Granger causality relationships for E7 countries 
between economic growth, energy consumption, and $\mathrm{CO}_{2}$ emissions to fine-tune their energy policies.

Policymakers should aim to improve energy efficiency based on a robust infrastructure that will enable businesses and households to use fossil fuels to generate clean energy. Their countries need to upgrade their high-cost/low-efficient energy technologies used for manufacturing goods to more efficient and less energydependent ones, in order to create a better environment and to promote societal changes. Specifically, these countries must invest in renewable energy and the promotion of technology transfers, to facilitate the generation of renewable energy.

\section{Conclusions}

In recent years, the economic growth-energy consumption-environment trinity has become a key issue for scholars and policymakers. Increased demand for energy and the subsequent $\mathrm{CO}_{2}$ pollution make both developed and developing countries vulnerable to the effects of global warming and climate change. This compels governments to create policies which aim to reduce $\mathrm{CO}_{2}$ emissions while concurrently creating new knowledge and expertise to supply the energy that is required for growth and development. However, while the worldwide effort is to achieve more efficient use of energy, E7 countries face a more substantial challenge. They have the task of achieving economic growth while simultaneously improving the efficiency of their energy consumption, reducing environmental pollution, and promoting $\mathrm{CO}_{2}$ emission-reduction strategies.

The political drive to take action against global warming is a sine qua non condition for both developed and developing countries. This motivates the creation and enactment of policies to produce environmentally sustainable energy and regulation of $\mathrm{CO}_{2}$ emissions resulting from the combustion of fossil fuels. It is, at the same time, the most questioned climate-friendly energy policy. This is because some countries see $\mathrm{CO}_{2}$ emissions as an irreversible threat to the planet while others, with poor environmental records, see it as an unfounded exaggeration lacking in any scientific evidence. The result of this conflict of attitude is an international diplomatic deadlock between proactive and lukewarm nations regarding the amelioration of $\mathrm{CO}_{2}$ emissions and promotion of sources of renewable energy. Such an impasse is compounded in the E7 countries by the sheer complexity of their environmental problems and pollution issues, the relatively high cost of carbon sequestration technologies, and the lack of mandatory enforceability. Consequently, unless the E7 nations secure an efficient infrastructure for energy conversion to adequately deliver various forms of clean energy at affordable prices, they will all fail to meet one of the most fundamental sustainable development goals advanced by the United Nations, that of reaching net zero $\mathrm{CO}_{2}$ emissions by 2030 .

Prior to this study, no research using the bootstrap ARDL bound test had been carried out on the E7 countries and only limited research existed on the direction of the causal relationship between economic growth, energy consumption, and $\mathrm{CO}_{2}$ emissions in general. This paper has responded to the call for research that enables governments to appropriately capture actual risk through stress testing using novel research methodologies. It has filled the gap in current literature by revisiting the cointegration and causality relations of $3 \mathrm{E}$ in the E7 countries with a distinctive variation of the bootstrap ARDL bound model. The results show there is a significant long-run cointegration among economic growth, energy consumption, and $\mathrm{CO}_{2}$ emissions, while evidence for cointegration exists for Brazil, India, and Russia.

This study confirms the presence of Granger causality from energy consumption to $\mathrm{CO}_{2}$ emissions. The global warming consequences of $\mathrm{CO}_{2}$ emissions have made it necessary for developed and developing countries to reduce fossil fuel consumption and promote the use of clean energy. The one-way and two-way causalities between economic growth and $\mathrm{CO}_{2}$ emissions, energy consumption, and $\mathrm{CO}_{2}$ emissions, and energy consumption and economic growth, also indicate that energy consumption is still growing in the E7 countries. Accomplishing significant global reductions in $\mathrm{CO}_{2}$ emissions requires both the tradeoff of slower economic growth and the achievement of coordinated sustainable environmental development. Standardization of research approaches would permit balancing out environmental risks and steady growth, while allowing each government to formulate specific energy development, $\mathrm{CO}_{2}$ reduction, and economic policies that encourage the use of renewable sources of energy while reflecting its own country's unique circumstances.

The results underscore the intertwined relationship between economic growth-energy consumption-environment in the E7 countries. Future research should look at identifying and quantifying the short- and long-term benefits and costs of $\mathrm{CO}_{2}$ reduction and mitigation strategies. This would permit policymakers to design the institutional framework for unified national energy standards, along with an assortment of subsidies and taxes and building and transportation codes, before making decisions on the alternatives available for disrupting the frequency and intensity of natural disasters associated with $\mathrm{CO}_{2}$ emissions. These alternatives should allow the E7 countries to move away from fossil fuels and focus on alternative technologies, including solar and wind as well as the development of low-carbon power plants based on gas and steam turbines. This research is not exempt from some limitations. A case in 
point is the data collection which could have included a much longer span time for each E7 country to capture more precisely their $3 \mathrm{E}$ relationships. Further research also needs to cast the net to a wider spectrum of wellknown global leaders of $\mathrm{CO}_{2}$ emissions to ensure these results hold in nations with unique social, legal, economic, political, and technological characteristics. There is still time for these governments to become more forceful in their efforts to act in order to slow down the pace with which our climate is changing around the world.

\begin{abstract}
Abbreviations
ARDL: Autoregressive distributed lagged (ARDL); E7 countries: Emerging 7 countries (Brazil, India, Indonesia, Mexico, People's Republic of China, Russia, and Turkey); GDP: Gross domestic product; 3E: Economic growth, energy consumption, and $\mathrm{CO}_{2}$ emissions; $\mathrm{CO}_{2}$ : Carbon dioxide; $\mathrm{BP}$ : British Petroleum; SDGs: Sustainable Development Goals; IEA: International Energy Agency; PWC: Price, Waterhouse, and Coopers; G7: Group of 7: EKC: Environmenta Kuznets Curve; BRIC: Brazil, Russia, India, and People's Republic of China EC: Energy consumption; FD: Financial development; VAR: Vector Autoregressive Model; VECM: Vector Error Correction Model; Kgoe: Kilogram of oil equivalent; mt: Metric tons; ADF: Augmented Dickey-Fuller; PP: Phillips and Perron; KPSS: Kwiatkowski-Phillips-Schmidt-Shin; LGDP: Logarithm of per-capita GDP; LEC: Logarithm of per-capita primary energy consumption; $\mathrm{LCO}_{2}$ : Logarithm of per-capita $\mathrm{CO}_{2}$ emissions; LS: Lee and Strazicich; ZA: Zivot and Andrew; AIC: Akaiki Information Criterion
\end{abstract}

\section{Acknowledgements}

None.

\section{Authors' contributions}

Jaime Ortiz supervised the research from the beginning to the end. Teng Tong conceived the study and drafted the manuscript. Chuanhua Xu collected the data. Fangihy Li estimated the econometric model. All authors made suggestions throughout the entire manuscript. The authors read and approved the final manuscript.

\section{Funding}

This study was supported by the Hubei Provincial Department of Education Humanities and Social Sciences project (funding no. 16Q207), the Research Center of Hubei Financial Development and Financial Security, and the People's Republic of China Scholarship Council (CSC 201808420340).

\section{Availability of data and materials}

All data used in this study are publicly available online. The information on the sources of data is provided in the references.

Ethics approval and consent to participate

Not applicable

\section{Consent for publication}

Not applicable

\section{Competing interests}

The authors declare that they have no competing interests.

\section{Author details}

'School of Finance, Hubei University of Economics, Wuhan 430205, People's Republic of China. ${ }^{2}$ College of Technology, University of Houston, Isabel C. Cameron Bldg. Suite. 227 D, 4235 Cullen Blvd., Houston, TX 77204, USA.
Received: 20 December 2019 Accepted: 30 March 2020

Published online: 16 April 2020

\section{References}

1. Cheng BS, Lai TW (1997) An investigation of co-integration and causality between energy consumption and economic activity in Taiwan. Energy Econ 19(4):435-444

2. Ghosh S (2002) Electricity consumption and economic growth in India. Energy Policy 30:125-129

3. Kraft J, Kraft A (1978) On the relationship between energy and GNP. J Energy Dev::401-403

4. Lee CC (2005) Energy consumption and GDP in developing countries: a cointegrated panel analysis. Energy Econ. 27:415-427. https://doi.org/10. 1016/j.eneco.2005.03.003

5. Jobert T, Karanfil F (2007) Sectoral energy consumption by source and economic growth in Turkey. Energy Policy 35:5447-5456. https://doi.org/10. 1016/j.enpol.2007.05.008

6. Apergis $\mathrm{N}$, Payne JE (2009) $\mathrm{CO}_{2}$ emissions, energy usage, and output in Central America. Energy Policy 37:3282-3286. https://doi.org/10.1016/j.enpol. 2009.03.048

7. Naser H (2015) Analyzing the long-run relationship among the oil market, nuclear energy consumption, and economic growth: an evidence from emerging economies. Energy 89:421-434. https://doi.org/10.1016/j.energy. 2015.05.115

8. Chen PY, Chen ST, Hsu CS, Chen CC (2016) Modeling the global relationships among economic growth, energy consumption, and $\mathrm{CO}_{2}$ emissions. Renew Sustain Energy Rev. 65:420-431. https://doi.org/10.1016/j. rser.2016.06.074

9. Sadorsky P (2009) Renewable energy consumption, $\mathrm{CO}_{2}$ emissions and oil prices in the G7 countries. Energy Econ. 31:456-462. https://doi.org/10.1016/ j.eneco.2008.12.010

10. Wang SS, Zhou DQ, Zhou P, Wang QW (2011) $\mathrm{CO}_{2}$ emissions, energy consumption and economic growth in China: a panel data analysis. Energy Policy 39:4870-4875. https://doi.org/10.1016/j.enpol.2011.06.032

11. Raza SA, Shahbaz M, Nguyen DK (2015) Energy conservation policies, growth, and trade performance: evidence of feedback hypothesis in Pakistan. Energy Policy 80:1-10. https://doi.org/10.1016/j.enpol.2015.01.01

12. Grippa P, Schmittmann J, Suntheim F (2019) Climate change and financial risk. Finance Dev 56(4):26-29

13. United Nations, "Transforming our world: the 2030 agenda for sustainable development". - Sustainable development knowledge platform. Retrieved 23 August 2015

14. Cui L, Huang Y (2018) Exploring the schemes for green climate fund financing: international lessons. World Dev. 101:173-187. https://doi.org/10. 1016/j.worlddev.2017.08.009

15. Doğan B (2018) The role of economic growth and energy consumption on CO2 emissions in E7 countries XXV, 231-246

16. International Energy Agency (IEA), https://www.iea.org/geco/.

17. PWC, The Long view, How will the global economic order change by 2050? (https://www.pwc.com.au/government/pwc-the-world-in-2050-full-reportfeb-2017.pdf)

18. Hawksworth, John, Cookson Gordon.2006. "The world in 2050" PricewaterhouseCoopers.

19. Park G (2016) Integral operational leadership: a relationally intelligent approach to sustained performance in the twenty-first century. Routledge ISBN 9781317070863

20. BP Statistical Review of World Energy Reports, 2018. (https://www.bp.com/ en/global/corporate/energy-economics/statistical-review-of-world-energy. html)

21. Pao H-T, Chen C-C (2019) Decoupling strategies: $\mathrm{CO}_{2}$ emissions, energy resources, and economic growth in the Group of Twenty. J Clean Prod. 206: 907-919. https://doi.org/10.1016/j.jclepro.2018.09.190

22. Yang Z, Zhao Y (2014) Energy consumption, carbon emissions, and economic growth in India: evidence from directed acyclic graphs. Econ Model. 38. https://doi.org/10.1016/j.econmod.2014.01.030

23. Ozturk I, Acaravci A (2010) CO2 emissions, energy consumption and economic growth in Turkey. Renew Sustain Energy Rev. 14:3220-3225. https://doi.org/10.1016/j.rser.2010.07.005

24. Asongu S, El Montasser G, Toumi H (2016) Testing the relationships between energy consumption, $\mathrm{CO}_{2}$ emissions, and economic growth in 24 
African countries: a panel ARDL approach. Environ Sci Pollut Res. 23:6563$6573 \mathrm{https} / / / \mathrm{doi}$. org/10.1007/s1 1356-015-5883-7

25. Ahmad N, Du L (2017) Effects of energy production and $\mathrm{CO}_{2}$ emissions on economic growth in Iran: ARDL approach. Energy 123:521-537 https://doi. org/10.1016/j.energy.2017.01.144

26. Pesaran MH, Shin Y, Smith RJ (2001) Bounds testing approaches to the analysis of level relationships. J Appl Econ. 16:289-326 https://doi.org/10. 1002/jae.616

27. McNown R, Sam CY, Goh SK (2018) Bootstrapping the autoregressive distributed lag test for cointegration. Appl Econ. 50(13):1509e1521

28. Grossman, G.M., Krueger, A.B., 1995. Economic growth and the environment. Quarterly Journal of Economics, 60(2), 353-375.Published by : The MIT Press Stable URL : http://www.jstor.org/stable/2118443. Q. J. Econ. 110, 353-377.

29. Dinda S (2004) Environmental Kuznets curve hypothesis: a survey. Ecol Econ. 49:431-455 https://doi.org/10.1016/j.ecoLECon.2004.02.011

30. Soytas U, Sari R, Ewing BT (2007) Energy consumption, income, and carbon emissions in the United States. Ecol. Econ. 62:482-489 https://doi.org/10. 1016/j.ecolecon.2006.07.009

31. Iwata H, Okada K, Samreth S (2010) Empirical study on the environmental Kuznets curve for $\mathrm{CO}_{2}$ in France: the role of nuclear energy. Energy Policy 38:4057-4063 https://doi.org/10.1016/j.enpol.2010.03.031

32. Dietz T, Rosa EA (1994) Rethinking the environmental impacts of population, affluence and technology. Human Ecology Review 1:277-300

33. Özokcu S, Özdemir Ö (2017) Economic growth, energy, and environmental Kuznets curve. Renew Sustain Energy Rev. 72:639-647 https://doi.org/10. 1016/j.rser.2017.01.059

34. Friedl $\mathrm{B}$, Getzner $\mathrm{M}$ (2003) Determinants of $\mathrm{CO}_{2}$ emissions in a small open economy. Ecol Econ 45:133-148. https://doi.org/10.1016/S09218009(03)00008-9

35. Holtz-Eakin D, Selden TM (1995) $\mathrm{CO}_{2}$ emissions and economic growth. J Public Econ. 57:85-101

36. Agras J, Chapman D (1999) A dynamic approach to the environmental Kuznets curve hypothesis. Ecol Econ 28:267-277. https://doi.org/10.1016/ S0921-8009(98)00040-8

37. He J, Richard P (2010) Environmental Kuznets curve for $\mathrm{CO}_{2}$ in Canada. Ecol Econ. 69:1083-1093 https://doi.org/10.1016/j.ecoLECon.2009.11.030

38. Richmond AK, Kaufmann RK (2006) Is there a turning point in the relationship between income and energy use and/or carbon emissions? Ecol. Econ. 56:176-189 https://doi.org/10.1016/j.ecoLECon.2005.01.011

39. Stern, D.I., 1993. Energy and economic growth in the USA. Energy Econ. 15, 137-150. https://doi.org/10.1016/0140-9883 (93)90033-N

40. Salahuddin M, Gow J, Ozturk I, 2015. Is the long-run relationship between economic growth, electricity consumption, carbon dioxide emissions and financial development in Gulf Cooperation Council Countries robust? Renew Sustain Energy Rev. 51, 317-326. https://doi.org/10.1016/j.rser.2015. 06.005

41. Omri A, Nguyen DK, Rault C (2014) Causal interactions between $\mathrm{CO}_{2}$ emissions, FDI, and economic growth: evidence from dynamic simultaneous-equation models. Econ Model. 42:382-389 https://doi.org/10 1016/.econmod.2014.07.026

42. Ozturk I (2010) A literature survey on energy-growth nexus. Energy Policy 38:340-349 https://doi.org/10.1016/j.enpol.2009.09.024

43. Damette O, Seghir M (2013) Energy as a driver of growth in oil exporting countries? Energy Econ. 37:193-199 https://doi.org/10.1016/j.eneco.2012.12. 011

44. Ghali KH, El-Sakka MIT (2004) Energy use and output growth in Canada: a multivariate cointegration analysis. Energy Econ. 26:225-238 https://doi.org/ 10.1016/S0140-9883

45. Baranzini A, Weber S, Bareit M, Mathys NA (2013) The causal relationship between energy use and economic growth in Switzerland. Energy Econ. 36: 464-470 https://doi.org/10.1016/j.eneco.2012.09.015

46. Jamil F, Ahmad E (2010) The relationship between electricity consumption, electricity prices and GDP in Pakistan. Energy Policy 38:6016-6025 https:// doi.org/10.1016/j.enpol.2010.05.057

47. Belloumi M (2009) Energy consumption and GDP in Tunisia: cointegration and causality analysis. Energy Policy 37:2745-2753 https://doi.org/10.1016/j. enpol.2009.03.027

48. Lee CC, Chang CP, Chen PF (2008) Energy-income causality in OECD countries revisited: The key role of capital stock. Energy Econ. 30:2359-2373 https://doi.org/10.1016/j.eneco.2008.01.005
49. Tang CF, Tan BW (2014) The linkages among energy consumption, economic growth, relative price, foreign direct investment, and financial development in Malaysia. Qual Quant. 48:781-797 https://doi.org/10.1007/ s11135-012-9802-4

50. Pao HT, Tsai CM (2010) $\mathrm{CO}_{2}$ emissions, energy consumption and economic growth in BRIC countries. Energy Policy 38:7850-7860 https://doi.org/10. 1016/j.enpol.2010.08.045

51. Wang K, Zhu B, Wang P, Wei YM (2016) Examining the links among economic growth, energy consumption, and $\mathrm{CO}_{2}$ emission with linear and nonlinear causality tests. Nat Hazards 81:1147-1159 https://doi.org/10.1007/ s1 1069-015-2124-9

52. Magazzino $\mathrm{C}$ (2016) Economic growth, $\mathrm{CO}_{2}$ emissions and energy use in the south caucasus and Turkey: a PVAR analyses. Int Energy J. 16:153-162

53. Magazzino $\mathrm{C}$ (2017) The relationship among economic growth, $\mathrm{CO}_{2}$ emissions, and energy use in the APEC countries: a panel VAR approach. Environ Syst Decis. 37:353-366 https://doi.org/10.1007/s10669-017-9626-9

54. Mirza FM, Kanwal A (2017) Energy consumption, carbon emissions and economic growth in Pakistan: dynamic causality analysis. Renew Sustain Energy Rev. 72:1233-1240 https://doi.org/10.1016/.j.rer.2016.10.081

55. Jalil A, Mahmud SF (2009) Environment Kuznets curve for $\mathrm{CO}_{2}$ emissions: a cointegration analysis for China. Energy Policy 37:5167-5172 https://doi.org/ 10.1016/.enpol.2009.07.044

56. Magazzino C (2016) The relationship among real gross domestic product, CO2 emissions, and energy use in South Caucasus and Turkey. Int J Energy Econ Policy 6(4):672-683

57. Alam MM, Murad MW, Noman AHM, Ozturk I (2016) Relationships among carbon emissions, economic growth, energy consumption and population growth: testing environmental Kuznets curve hypothesis for Brazil, China, India and Indonesia. Ecol Indic. 70:466-479 https://doi.org/10.1016/j.ecolind. 2016.06.043

58. Goh SK, Yong JY, Lau CC, Tang TC (2017) Bootstrap ARDL on energy-growth relationship for 22 OECD countries. Appl Econ Lett. 24:1464-1467 https:// doi.org/10.1080/13504851.2017.1284980

59. Lin FL, Inglesi-Lotz R, Chang T (2018) Revisit coal consumption, $\mathrm{CO}_{2}$ emissions and economic growth nexus in China and India using a newly developed bootstrap ARDL bound test. Energy Explor Exploit. 36:450-463 https://doi.org/10.1177/0144598717741031

60. Phillips $P$, Perron $P$ (1988) Testing for a unit root in time series regression. Biometrika 75(2):335-346

61. Elliott G, Rothenberg TJ, Stock JH (1996) Efficient tests for an autoregressive unit root. Econometrica 64(4):813-836

62. Kwiatkowski D, Phillips PCB, Schmidt P, Shin Y (1992) Testing the null hypothesis of stationarity against the alternative of a unit root. How sure are we that economic time series have a unit root? J Econom. 54:159-178 https://doi.org/10.1016/0304-4076(92)90104-Y

63. Zivot $E$, Andrews D (1992) Further evidence on the great crash, the oil price shock, and the unit-root hypothesis. J Business Econ Stat 10(3):251-270

64. Lee J, Strazicich MC (2003) Minimum Lagrange multiplier unit root test with two structural breaks. Rev Econ Stat 85(4):1082-1089 https://doi.org/10. $1162 / 003465303772815961$

65. Bai J, Perron P (2003) Computation and analysis of multiple structural change models. J Appl Econom. 18:1-22 https://doi.org/10.1002/jae.659

\section{Publisher's Note}

Springer Nature remains neutral with regard to jurisdictional claims in published maps and institutional affiliations.

Ready to submit your research? Choose BMC and benefit from:

- fast, convenient online submission

- thorough peer review by experienced researchers in your field

- rapid publication on acceptance

- support for research data, including large and complex data types

- gold Open Access which fosters wider collaboration and increased citations

- maximum visibility for your research: over $100 \mathrm{M}$ website views per year

At $\mathrm{BMC}$, research is always in progress.

Learn more biomedcentral.com/submission 